\title{
Jigsaw Learning Model for Increasing Competence to Diagnose and Repaire Single Phase Motor Running- Capacitor Type
}

\author{
Edi Sarwono $^{1}$, Adi Kuncoro ${ }^{2}$
}

edisarwono@mail.unnes.ac.id ${ }^{1}$, kuncorokasih@gmail.com

Electrical Engineering Department, Universitas Negeri Semarang ${ }^{1}$, SMK N 1 Semarang, Indonesia ${ }^{2}$

\begin{abstract}
Vocational high school students are unusual to discussions in group to solve problems, because they get a curriculum that focuses on practice and industrial-oriented. This research aim so that vocational students can also become professionals in solving problems with discussions and practice. Jigsaw learning model is one of the methods of learning used in this research. Students can diagnose errors in one-phase electric motors through expert team discussions. This research took the data with pre-test and post-test, and also the practice test with the accuracy of diagnosing and repairing. The results showed the ability of students increased from the average value of 65.91 to 81.45 (23.58\%).
\end{abstract}

Keywords: Jigsaw Learning Model, Single Phase Motor, Competence.

\section{Introduction}

Indonesia is involved in the era of free markets and globalization in the fields of technology and labor. This demands to be more competitive in order to win the competition in the service and goods industries. therefore it demands to work and study harder and knows no time. The rapid development of Science and Technology demands changes in the world of education.

Learning with the lecture method is widely used. this model tends to be unidirectional in the delivery of subject matter. Student participation will be low because the teacher plays an active role. the teacher becomes a model in learning and becomes the center of knowledge for students. However the lecture method is still needed for some purposes. One of the improvements in the quality of vocational education in Indonesia can be done by learning in class [1]. Effective and efficient learning will get optimal output [2].

Teaching and learning activities must consider students more. Besides that, the learning flow does not have to come from the teacher to the students. Students can also teach each other with other students. The teaching system that provides opportunities for students to work with fellow students and structured tasks is called the mutual cooperation learning system. The teacher will be helped by this method because learning is student-centered [3][4][5].

Cooperative learning is one type of student-centered learning approach, much of the literature has documented that this approach is effective in assisting students in the learning 
process, effective communication and skills in understanding knowledge, and promoting students positive attitudes towards their own learning [6].

Slavin [7] states that cooperative learning is a teaching and learning strategy that emphasizes the attitude or behavior of working or helping each other in an organized cooperative structure in groups consisting of two or more people.

There are several kinds of learning models based on cooperative learning, including the Student Teams Achievement Divisions (STAD) cooperative learning model, Jigsaw, Group Investigation (GI), Numbered Heads Together (NHT), and Think Pair Share (TPS) [8]. Problem solving skills can be improved by the jigsaw method because students learn in small and specific groups [9].

This study only discusses the jigsaw model of cooperative learning. This is a learning model that is very encouraging to students because students are divided into heterogeneous groups (differences in gender, academic ability, and so on). study groups consisting of six to seven students.

\section{Method}

This research was conducted in the first semester of the 2019/2020 school year at SMK Negeri 1 Semarang, located on Jl.Dr. Cipto no 93 Semarang city. The sample used in this study is class XI TPTL 3 with a total of 34 students. The implementation of this research is an effort to improve the learning of Electrical Equipment Maintenance Subjects, Sub-discussion to diagnose and repair 1-phase electric motor errors in class XI.

The test used in this study consisted of 2 types, the pre-test which was carried out to determine the students 'initial knowledge or abilities, and the post-test which was used to measure the increase in students' abilities after the Jigsaw model learning was held.

Classroom action research is in the form of a spiral cycle which includes the following activities: (1) application, (2) action givers that form cycle to cycle until the research is considered complete, so that data can be collected as an answer to the problem [10]. The research was conducted in two cycles, namely cycle I and cycle II. Teachers and observers make observations of student learning activities during the implementation of the teaching and learning process using the jigsaw method. The results of the observations were analyzed as material for reflection to increase activities in cycle II.

Teacher conducts a pre-test at the beginning of the cycle before learning the jigsaw model to find out the students' initial knowledge or abilities about the material to be taught. Teacher also gives the final test (post-test) to students individually at the end of the jigsaw model learning to measure the extent to which the students' ability increases after the jigsaw model learning is held and students are not shown to cooperate with each other between group members.

\section{Result and Discussion}

\subsection{Data Analysis}

Data analysis is carried out every time the learning cycle ends. This analysis includes:

1. Student achievement

Evaluation results were analyzed to determine student learning completeness. The results of the evaluation were analyzed to determine the students' learning 
completeness by analyzing the formative test result data using mastery learning. Absorption of students can be known in this way. Students are called complete learning if they have reached a score of $\geq 60 \%$, and classical learning completeness, namely $\geq 85 \%$ of all students who achieve learning completeness. Quantitative data on learning completeness in Electrical Equipment Maintenance subjects in cycle I will be compared with quantitative data on learning completeness in cycle II.

2. Student learning activities

To determine student learning activities, the data contained in the observation sheet will be calculated. Calculation of the average frequency of student learning activities $\mathrm{K}, \mathrm{C}$, B using the formula as below [11]:

student learning activities $=\frac{\Sigma \text { Student } K, C, B}{\Sigma \text { Student } \text { with level } K, C, B} \times 100 \%$

With:

$\mathrm{K}=$ Less

$\mathrm{C}=$ Enough

$\mathrm{B}=$ Good

3. Student perceptions

The impression of students after participating in the jigsaw model learning is known by the questionnaire data filled out by the students. Quantitative calculations can be calculated based on the following formula as below :

$$
P=\frac{F}{N} \times 100 \% \%
$$

With:

$\mathrm{P}=$ Percentage that answered the options

$\mathrm{F}=$ Number of respondents who answered the option

$\mathrm{N}=$ Number of respondents

\subsection{Result}

Researchers can show that the average value in the first cycle of 65.91 becomes the average value to 81.45 , which means that it has increased to $23.58 \%$, with an average value of 81.45 which means that it has passed the minimum limit of the average productive training eye, which is 70.00, shown in Figure 1.

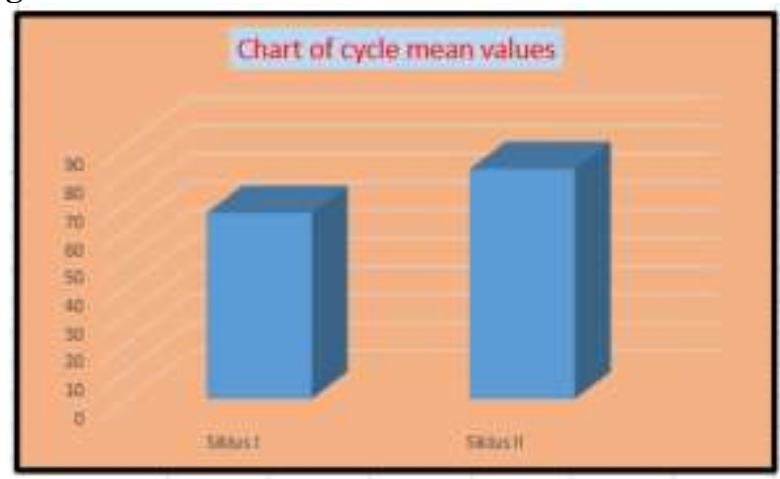

Fig. 1. Chart comparison cycle I \& cycle 2 


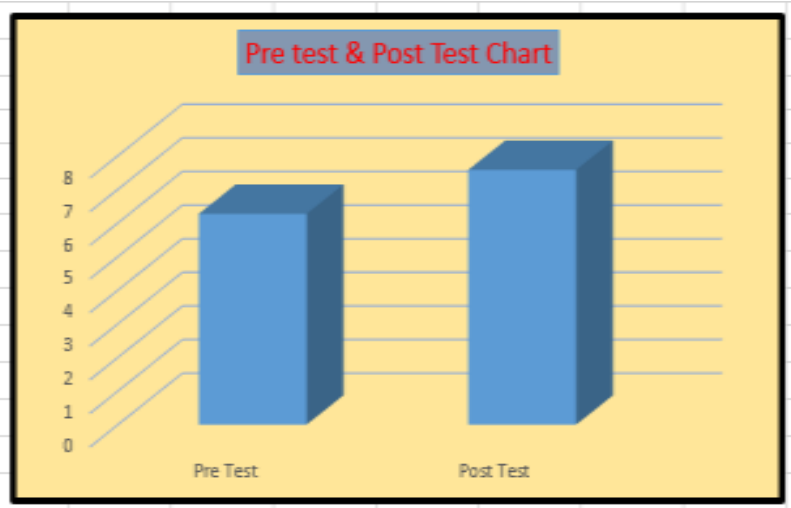

Fig. 2. Chart comparison pre test dan post test

The researcher ensured that for the thoroughness of the study, the students carried out a post test to find out that there were significant changes from not knowing to knowing and understanding better. With the results of the post test, it can be seen from the results in Figure 2. By looking at the comparison chart, you get a better picture of the increase to be seen from the average value and statistical approach. The post-test uses multiple choice tests with the same questions as the pre-test.

To find out students 'activities and perceptions, researchers also used questionnaire data given to students about the students' viewpoints to accept the jigsaw learning method with the following results: Researchers divided into 4 categories, namely: a score of 10-20 means no interest; 21-40 means less interest; 31-40 means quite interested; 41-50 means interested.

Table 1. Table of students activities and perceptions

\begin{tabular}{llcccccc}
\hline No & Observed & Less $(\mathrm{K})$ & Enough $(\mathrm{C})$ & Good $(\mathrm{B})$ & $\mathrm{K} \%$ & $\mathrm{C} \%$ & $\mathrm{~B} \%$ \\
\hline 1 & Interaction & 16 & 15 & 3 & 47.12 & 44.12 & 8.82 \\
2 & Responsible & 24 & 10 & 0 & 70.59 & 29.41 & 0 \\
3 & $\begin{array}{l}\text { Positive } \\
\text { interdependence }\end{array}$ & 4 & 23 & 7 & 11.76 & 67.65 & 20.59 \\
4 & Member & 2 & 16 & 16 & 5.88 & 47.06 & 47.06 \\
5 & Evaluation & 0 & 34 & 0 & 0 & 100 & 0 \\
\hline
\end{tabular}

From Table 1, the researcher wants to show student interaction with the discussion, the highest percentage is in the low score, responsibility also ranks the highest at $70.59 \%$, the highest percentage of communication lies in Good at $47.06 \%$, Evaluation of the percentage in sufficient condition is $100 \%$ of XI TPTL 3 students in conditions are neither less nor good. The results that have been achieved in this study are unsatisfactory because of the lack of support for student activeness, but in terms of practice of the material taught, students get quite encouraging standards with the value of practice that continues to increase beyond the standard limit for vocational 


\section{Conclusion}

In this classroom action research, the conclusion is that: (1) The jigsaw learning model has increased the competence of students with an average score of 65.91 to 81.45. It shows that there was an increase of $23.58 \%$. (2) Pre-test and post-test data showed an increase in the average value from 6.27 to 7.58 . (3) Jigsaw learning model received a good enough response from students with enough interested category. (4) The activeness of students in the discussion of the jigsaw model is still low in the enough category.

\section{References}

[1] Subiyantari, A., R., Muslim, S., Rahmadyanti, E.(2019). Effectiveness of Jigsaw Cooperative Learning Models in Lessons of the Basics of Building Construction on Students Learning 'Outcomes Viewed from Critical Thinking Skills. International Journal for Educational and Vocational Studies, 1(7),691-696

[2] Noviandari, H., \& Mursidi, A. (2019). Relationship of Self Concept, Problem Solving and Self Adjustment in Youth. International Journal for Educational and Vocational Studies, 1(6).651-657

[3] Azmin, N. H. (2015). Effect of the jigsaw-based cooperative learning method on student performance in the general certificate of education advanced-level psychology: an exploratory Brunei case study. International Education Studies, 9(1), 91

[4] Dasining, D., Muslim, S., \& Handajani, S. (2019). The Effect of Problem Based Learning Models and Levels of Creativity Toward Student Outcomes in Vocational High School. International Journal for Educational and Vocational Studies, 1(6).595-598

[5] Erma, E., Koeswanti, H. D., \& Giarti, S. (2019). Improving Critical Thinking Skills Using Problem Based Learning on the Media Flash Card. International Journal for Educational and Vocational Studies, 1(6).619-622

[6] Tran, V.D., Faculty, L. \& Published, O., 2012. The Effects of Jigsaw Learning on Students 'Attitudes in a Vietnamese Higher Education Classroom. International Journal of Higher Education, 1(2), pp.9-20

[7] Slavin, R.E., 1995. Instruction Based on Cooperative Learning. , pp.0-31

[8] Nurhadi, Y. B., \& Senduk, A.G. 2004. Pembelajaran Kontekstual dan Penerapannya dalam KBK. Malang: UM Press

[9] Buhr, G. T., Heflin, M. T., White, H. K., \& Pinheiro, S. O. (2014). Using the jigsaw cooperative learning method to teach medical students about long-term and postacute care. Journal of the American Medical Directors Association, 15(6), 429434

[10] Tim pelatih Proyek PGSM. 1999. Penelitian Tindakan Kelas. Jakarta : Departemen Pendidikan dan Kebudayaan

[11] Mutomimah, S. 2016. Peningkatan Prestasi Belajar Siswa Tentang Jurnal Khusus Melalui Penerapan Pembelajaran Kooperatif Model JigsawKelas XII IPS 2 SMA Negeri I Jogorogo, JIPE Vol.I No. 2 Edisi September 2016 